\title{
In Memoriam: Professor Emeritus Božidar Jelčić
}

HRVOJE ARBUTINA, Ph.D.*

https://doi.org.10.3326/pse.41.1.6

\footnotetext{
* Received: February 7, 2017
}

Accepted: February 10, 2017

Hrvoje ARBUTINA

Faculty of Law, University of Zagreb, Trg maršala Tita 14, 10000 Zagreb, Croatia e-mail: hrvoje.arbutina@pravo.hr ORCID iD: 0000-0003-4883-8606 
When I was an assistant professor, I had just finished examining my students and was leaving the office. On the other end of our small hallway I noticed that one of my students, whom I had failed before, was leaving Professor Jelčić's office. I asked: "How did it go?" "I passed," he said. I said: "You see, it wasn't that bad." And he replied "True, but when you gave the exam, it was stressful; with professor Jelčić, it was like having a conversation."

Professor emeritus Božidar Jelčić (1930-2017) has passed away at the age of 87. His entire career right up to his retirement - almost forty five years - were spent at the Faculty of Law of the Zagreb University, at the Department of Financial Law and Financial Science, and he devoted most of his work to the Faculty. At forty, he was the youngest full professor at the Zagreb University. For almost two decades he served as the chair of the Department of Financial Law and Financial Science; he was the dean of the Faculty of Law and served two terms as the vicerector of the University of Zagreb, where he was a fervent promoter of publishing and was dedicated to allocating grants for University publications and resolving University staff's housing issues.

He was not only dedicated to the Faculty - he was the founder and first director of the University Institute of Public Finance, which later became the Institute of Public Finance and still exists as an internationally renowned institution pursuing a number of diverse projects. He took part in the establishing of this journal and was member of the Editing Board for many years, publishing papers of his own and reviewing papers by other authors.

Professor Jelčić first graduated from the Divulje Navy Military Academy. Following graduation, he fell seriously ill for two years and then graduated in less than four years and at the top of his class from the Faculty of Law in Zagreb, where he started working and where he remained until retirement.

Professor Jelčić's scientific research was intensive and productive. He received a Humboldt fellowship and earned his doctorate under the tutelage of Professor Fritz Neumark, one of the most prominent experts in public finance, having written his thesis on turnover tax. He continued to work in this field and remained a leading expert, and his papers continue to be a fundamental source for all who research any type of turnover tax. He spent several long periods abroad and would always come back full of new impressions, not only professional but those gathered in his free time as well, and his stories were always interesting and funny.

His scientific interest was also devoted to the complex topic of education financing, which was the subject matter of several papers and the books "Education Financing" and "Organization and Financing of Education in the USA". He was the author of the first comprehensive textbook "Finance as a Science and Financial Law", in which he incorporated the scientific aspect of public finance and public finance law. Later he periodically updated and expanded the textbook and published it under the title "Financial Law and Finance as a Science". 
Professor Jelčić's opus is more than impressive: he wrote 25 books and more than 260 papers and was the author of various scientific and professional studies. This was the result of his exceptional self-discipline and work habits acquired during his years at the Navy Military Academy.

Let us mention only some of the many acknowledgments he received: honorary doctorate from the Taras Shevchenko National University in Kiev; national award "Ivan Filipović" for scientific contribution to the study of the economic aspects of education; national award for scientific work "Božidar Adžija"; he was elected associate member of the Croatian Academy of Sciences and Arts, received the Croatian Academy of Sciences and Arts award for his book "Financial Law and Finance as a Science", and was named Professor Emeritus by the University of Zagreb.

Professor Jelčić always showed the greatest consideration for teaching and for relations with his colleagues and students. Some of the most memorable lessons and pieces of advice I received from him were about how it was necessary to remain absolutely professional when it came to all manners of teaching and all kinds of relations with students and colleagues. He was a favourite teacher among his students, as both the above anecdote and excellent student reviews show. He was patient and considerate towards all students, never having shown a slightest sign of excessive strictness or arrogance. He can serve as role model to many younger colleagues; without any doubt, he was one to me.

Professor Jelčić's role as one of the founders of the postgraduate course "Fiscal System and Fiscal Policy", which is one of the doctoral and specialist postgraduate courses available at the Faculty of Law, established in 1998 and still in existence, is most noteworthy. He was also one of the founders and first members of the Croatian Academy of Legal Sciences, where his enthusiasm was an inspiration for all.

Professor Jelčić was always profoundly interested in the practical side of the functioning of the tax system. This interest inevitably led him to researching the relationship between the tax administration and the taxpayer. As a result of that research, he co-founded the Croatian Taxpayer's Association in 1992 and, for years to come, served as its president. The Association actively promoted taxpayers' interests, reacting to Government's tax reform proposals and initiating proposals to facilitate better understanding of the sides in that, sometimes troublesome, relationship.

Professor Jelčić had a profound impact on me. He was my master's thesis mentor and my doctoral thesis mentor as well. He was an unobtrusive mentor (of a kind which is perhaps rarer than one would think) - he was always there and ready to help when I didn't know how to go on or if I had a question regarding the writing of the thesis, discreetly encouraging me when I wouldn't come to him for advice for a while. He would never insist and require that I present results immediately. Owing to his balanced approach, the writing of these comprehensive works was as stress-free as possible, with just the right amount of positive stress that prevented me from becoming too relaxed and unproductive. 
Professor Jelčić was good company and easy to get along with. He would always find a conversation topic, he showed genuine interest in the other person's situation and found it easy to switch from professional to private topics; beyond doubt, all Department members and Faculty staff who were in contact with him shared the same sense of ease and non-existence of any inappropriate tensions. One of the Professor's traits was his highly developed, but refined sense of humour, far from ever being personally offensive or aggressive. Some of his remarks, especially those regarding taxes, tax reforms and persons involved in taxation make me laugh to this very day. This is something I will miss immensely.

But I will miss talking about professional topics as well. Department members would turn to such topics whenever they would spend more than a few minutes together and Professor Jelčić was the one who would somehow naturally take the role of moderator, since public finance and all its aspects - legal, economic, sociological and psychological - was his true professional passion. Anyone with a slightest knowledge of public finance could count on having an interesting and up-to-date discussion with the Professor and learning a thing or two.

Regarding his private life, family was a high priority for Professor Jelčić, a place where he found the strength and encouragement for his dedicated day-to-day scientific research and teaching.

For him, retirement was but a fact pertaining to labour law or, to put it in legal Latin terms, res inter alios acta. Professor Jelčić was an energetic researcher and teacher and the fact that he continued his work at the Libertas University was not surprising. This was an excellent chance to continue to do what he did best. He also served as the rector of the Libertas University and always enthusiastically talked about his work there. Given the fact that the University was extremely happy to have him, it was truly a win-win situation. But this was typical of Professor Jelčić; for him, any unnecessary energy-wasting or time-consuming conflicts were simply unacceptable.

Only in the last several conversations that we had would I hear a faintest trace of resignation in his voice, but this would never last: in the very next sentence we would return to taking about tax rates, taxpayers, justified or unjustified tax exemptions, and the ubiquitous topic of tax fairness. This is how I will remember the Professor-immersed in both professional and mundane topics and discussions, with a hint of contempt for the ephemerality of human life.

A lot more could be said about Professor Jelčić and about what he wrote and said, whether as a public figure, a university professor, or a private person. When I first came to the Department, I met the Professor; through my work and, I am proud to say, cooperation with Professor Jelčić, almost imperceptibly, I got to know the man. To bid farewell to him as a man is much, much harder.

Professor Jelčić, may you rest in peace. You will always be remembered. 